\title{
Aplikasi Kurva Derivative Dalam Penentuan Batas Reservoir Pada Sistem Reservoir Lensa
}

\author{
Oleh : \\ Fiki Hidayat* \\ Program Studi Teknik Perminyakan Universitas Islam Riau
}

\begin{abstract}
Abstrak
Reservoir lensa merupakan reservoir yang memiliki bentuk menyerupai lensa dan memiliki sifat reservoir yang tertutup. Saat ini, reservoir dengan tipe lensa mulai banyak diproduksikan. Studi mengenai reservoir lensapun telah banyak dilakukan untuk dapat lebih memahami kelakuan reservoir ini. Untuk memperoleh analisa lebih baik mengenai reservoir lensa ini diperlukan studi-studi yang tepat sehingga pengembangan lapangan dengan reservoir ini berjalan dengan baik. Analisa yang dilakukan salah satunya adalah analisa mengenai batas reservoir dengan menggunakan kurva derivative pada reservoir lensa ini. Untuk itu, yang perlu dilakukan adalah membuat model reservoir lensa dan melakukan simulasi untuk dapat memperkirakan kelakuan dari reservoir ini. Data yang diperlukan antara lain: tekanan reservoir, waktu produksi, batas reservoir, properti fluida, dan properti batuan. Dari data tersebut kemudian digunakan software simulasi reservoir CMG untuk memperoleh data tekanan dari sumur uji dan software Saphire untuk interpretasi dari data tekanan yang diperoleh. Pada penelitian ini akan dibahas tentang identifikasi dan analisa batas reservoir untuk reservoir dengan tipe lensa dengan menggunakan model ideal pada software Saphire. Selain itu, akan dibahas pula bentuk kurva derivative yang dihasilkan dari reservoir lensa.
\end{abstract}

Kata kunci: radius investigasi, kurva derivative, jari-jari pengurasan, periode transien, heterogenitas

\begin{abstract}
The lenticular reservoir is a reservoir that look like a lens and has heterogeneties type. Nowadays, this kind of reservoir have been started to produced. Studies about lenses reservoir have been done for better understand about reservoir behaviour. For get the better analysed about this reservoir, we need to do correct studies so that the field development of lenses reservoir will have great result. For that, we need to make a model of lenses reservoir and run a simulation to predict the behaviour of the reservoir. Data which required to make a model are reservoir pressure, production time, reservoir limit radius, fluid properties, and rock properties. From that data, CMG is used to acquire data of pressure from the testing well and interpret these data with Saphire. In this final assigment, it will be discussed about identification and analize reservoir limit for reservoir with lens type that is used ideal model in Saphire. Moreover, it willbe discussed about shape of the derivative curve of the lenticular reservoir.
\end{abstract}

Keywords: radius of investigation, derivative curve , drainage radius, transient period, heterogeneity

Corresponding author e-mail: fikihidayat@eng.uir.ac.id

\section{PENDAHULUAN}

Reservoir dengan tipe lensa telah banyak ditemukan dan populer terutama di Amerika Serikat. Berbagai penelitian (Warpinski, et al., 1985; Lorenz, 1985; Boardman \& Knutson, 1981; Evans \& Carroll, 1981; Craig \& Brown, 1999; Zubari \& Abdulwahab, 1999) telah dilakukan untuk dapat mengenali lebih dalam sifat dan karakter dari reservoir tersebut.

Studi yang dilakukan salah satunya berupa studi mengenai estimasi tekanan pori dan permeabilitas (Craig \& Brown, 1999). Boardman dan Knutson (Boardman \& Knutson, 1981) melakukan analisis dengan memanfaatkan data produksi gas, log sumur, dan data pressure buildup untuk menentukan 
volume dan permeabilitas reservoir. Lorenz (Lorenz, 1985) mengestimasi ukuran dan orientasi dari reservoir lensa. Estimasi ukuran dilakukan dengan dua cara, yaitu: (1) korelasi antara sumur dan sumur/metode probabilitas dan (2) analogi terhadap ratio ketebalan dan lebar reservoir dengan ratio outcrop reservoir lensa yang terkekspos di permukaan.

Berdasarkan penelitian Lorenz, estimasi ukuran dari reservoir lensa dapat dilakukan dengan menggunakan konsep radius investigasi, perhitungan radius batas reservoir dengan menggunakan kurva derivative dari reservoir lensa ini (Lee, 1982). Dalam pengujian sumur, radius investigasi atau jari-jari pengamatan sangat berguna dalam membantu menentukan batas reservoir. Dengan melakukan studi yang baik, dapat diperoleh informasi lebih jauh mengenai kelakukan reservoir lensa sehingga nantinya dapat lebih mudah menentukan batas reservoir untuk reservoir lensa dan properti lainnya.

Tujuan dari penelitian ini adalah untuk mengidentifikasi dan menganalisa batas reservoir untuk reservoir dengan tipe lensa dengan menggunakan model ideal pada software Saphire. Selain itu, dalam penelitian ini akan dibahas pula bentuk kurva derivative yang dihasilkan dari reservoir lensa. Sehingga dengan dikenalinya reservoir lensa ini lebih mendalam, pengembangan reservoir lensa akan menjadi lebih mudah seperti penentuan lokasi sumur produksi baru.

\section{TEORI DASAR}

Konsep radius investigasi, secara kualitatif dan kuantitatif, mempunyai arti yang sangat penting baik di dalam analisa maupun perencanaan suatu pengujian sumur. Radius of investigation menggambarkan sejauh mana pencapaian transien tekanan ke dalam formasi apabila diberikan gangguan keseimbangan tekanan akibat suatu produksi atau penutupan sumur. Jarak yang ditempuh oleh transien tekanan berhubungan dengan sifat-sifat fisik batuan dan fluida formasinya dan juga tergantung kepada lamanya waktu pengujian.

Sebuah formasi dengan sumur yang homogen dan isotermal, dengan ketebalan seragam, porositas dan permeabilitas konstan, serta memiliki aliran radial satu fasa, dideskripsikan oleh Lee (Lee, 1982) dalam persamaan difusi tak berdimensi yang merupakan kombinasi dari hokum kekekalan massa, persamaan keadaan, dan persamaan Darcy (Matthews \& Russell, 1967; van Everdingen \& Hurst, 1949; Hubbert, 1940; Horner, 1951) sebagai berikut:

$$
\begin{aligned}
& \frac{\partial^{2} p_{D}}{\partial r_{D}^{2}}+\frac{1}{r_{D}} \frac{\partial p_{D}}{\partial r_{D}}=\frac{\partial p_{D}}{\partial t_{D}} \quad \\
& p_{D}=\frac{k h\left(p_{i}-p\right)}{141.2 q \mu B} \\
& t_{D}=\frac{0.0002637 k t}{\mu c_{t} \emptyset r_{w}^{2}} \\
& r_{D}=\frac{r_{e}}{r_{w}}
\end{aligned}
$$


Kemudian, dengan anggapan ukuran radius formasi tidak terhingga, sehingga ukuran lubang sumur dapat diabaikan atau mendekati sama dengan nol, kemudian diproduksikan dengan laju produksi yang konstan, dan tekanan awal di seluruh titik formasi adalah sama dan sumur yang terlihat hanya berupa garis ini menguras area yang tak terhingga besarnya, Solusi analitikal dari Lee dijelaskan sebelumnya oleh Earlougher (Earlougher Jr, 1977) dalam persamaan formasi yang tidak terbatas sebagai berikut:

$$
p_{D}=-\frac{1}{2} E i\left(\frac{r_{D}^{2}}{4 t_{D}}\right)
$$

Atau bisa dijabarkan kembali dalam satuan lapangan menjadi persamaan sebagai berikut:

$$
p=p_{i}+70.6 \frac{q \mu B}{k h} E i\left(\frac{-948 \mu c_{t} \emptyset r^{2}}{k t}\right)
$$

dimana

$$
-E i(-x)=E i(x)=\int_{x}^{\infty} \frac{e^{-u}}{u} d u
$$

(Fungsi $E i=$ Eksponensial integral)

Untuk menentukan besarnya radius investigasi, Lee (Lee, 1982) telah menetapkan bahwa kuadrat dari radius investigasi tak berdimensi memiliki hubungan linear dengan waktu tak berdimensi. Hubungan ini ditunjukkan dalam persamaan:

$$
r_{i D}^{2}=4 t_{D}
$$

Atau jika dijabarkan dalam satuan lapangan akan menjadi persamaan sebagai berikut:

$$
r_{i}=\sqrt{\frac{k t}{948 \emptyset \mu c_{t}}}
$$

Radius investigasi, $r_{i}$, yang diberikan oleh persamaan (9) menggambarkan suatu jarak dimana gangguan tekanan,baik turun maupun naik, cukup berarti akibat produksi atau injeksi fluida dengan laju yang tetap.

Persamaan (8) dapat digunakan untuk memperkirakan waktu untuk mencapai stabilized flow, yaitu waktu yang diperlukan oleh transien tekanan untuk mencapai batas reservoir yang sedang diuji. Sebagai contoh, jika sumur yang diuji terletak di pusat reservoi yang berbentuk silinder yang terbatas, $\mathrm{r}_{\mathrm{e}}$, dengan menuliskan $\mathrm{r}_{\mathrm{i}}=\mathrm{r}_{\mathrm{e}}$, maka waktu yang diperlukan untuk mencapai stabilized flow tersebut adalah:

$$
t_{s}=\frac{948 \Phi \mu c_{t} r_{E}^{2}}{k}
$$


Untuk menggunakan konsep jari-jari pengamatan ini, kita harus menyadari sepenuhnya bahwa konsep ini akan memberikan hasil yang sangat teliti jika dan hanya jika formasi yang diselidiki mempunyai sifat-sifat homogen, isotropik, dan berbentuk silinder. Adanya keheterogenan suatu reservoir akan mengurangi ketelitian persamaan (9) dan (10). $t_{s}$ tidak bergantung pada laju aliran. Berapapun laju aliran yang diberikan akan meraih jarak yang sama pada suatu $t_{\mathrm{s}}$ yang sama.

Melalui pendekatan derivative, perubahan waktu terhadap perubahan tekanan selama periode pengujian menjadi pertimbangan untuk dilakukannya analisa. Dengan menggunakan logaritmik natural, derivative dapat dinyatakan sebagai fungsi derivative waktu, dan dikalikan dengan waktu $\Delta \mathrm{t}$ sejak periode awal.

$$
\Delta p^{\prime}=\frac{d p}{d \ln \Delta t}=\Delta t \frac{d p}{d t}
$$

Derivative diplot dalam koordinat $\log -\log$ vs $\Delta \mathrm{t}$

\section{MODEL RESERVOIR}

Untuk mempresentasikan kondisi reservoir pada penelitian ini maka dibuatlah model reservoir menggunakan simulator CMG. Model reservoir utama berbentuk persegi panjang dengan ukuran luas $20100 \mathrm{ft}$ x $5100 \mathrm{ft}$ dan terbagi dalam 201 grid x 51 grid. Tebal reservoir sebesar $150 \mathrm{ft}$ yang terbagi dalam 30 grid. Reservoir berada pada kedalaman $1500 \mathrm{ft}$ dari permukaan.

Kemudian dari model reservoir tersebut, digunakan fungsi sector untuk membuat model reservoir lensa dari model reservoir awal yang berbentuk balok tersebut. Model yang dihasilkan mempunyai bentuk seperti lensa cekung, ditunjukkan oleh gambar 1. Pada daerah sector, diberikan pengaturan null block sehingga hanya daerah di luar sector yang memiliki nilai properti seperti permeabilitas, porositas, dan kompresibilitas.

Model reservoir ini memiliki harga porositas sebesar $20 \%$, permeabilitas sebesar $100 \mathrm{mD}$, dan kompresibilitas sebesar $3 \times 10^{-6} 1 / \mathrm{psi}$. Model reservoir yang akan dikembangkan memiliki karakteristik solution gas reservoir seperti yang tertera pada Tabel 1 dan data PVT dari model reservoir yang digunakan dalam simulasi tertera pada Tabel 2.

Tabel 1 Properti Fisik Reservoir

\begin{tabular}{|l|c|l|}
\hline Kedalaman & $=$ & $1500 \mathrm{ft}$ \\
\hline Tekanan awal reservoir & $=$ & $4000 \mathrm{psia}$ \\
\hline $\begin{array}{l}\text { Tekanan gelembung } \\
\text { reservoir }\end{array}$ & $=3000 \mathrm{psia}$ \\
\hline Temperatur reservoir & $=$ & $321 \mathrm{~F}$ \\
\hline Permeabilitas & $=$ & $100 \mathrm{mD}$ \\
\hline Porositas & $=20 \%$ \\
\hline $\begin{array}{l}\text { Kompresibilitas formasi } \\
\text { batuan }\end{array}$ & $=\begin{array}{l}3 \times 10^{-6} \\
\mathrm{psi}^{-1}\end{array}$ \\
\hline
\end{tabular}




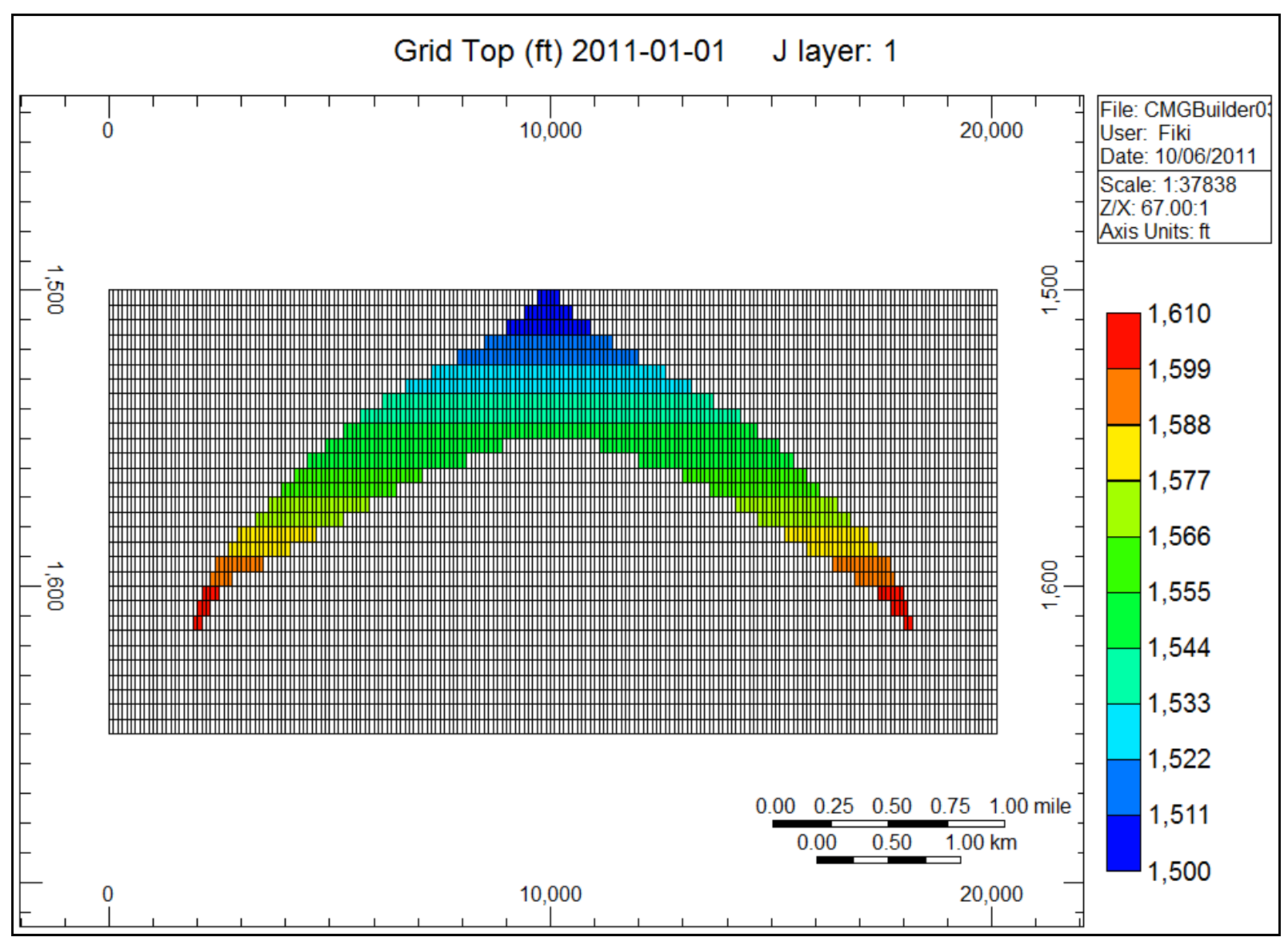

Gambar 1 Model Reservoir lensa

Tabel 2 Properti Fluida

\begin{tabular}{|c|c|c|c|c|c|}
\hline $\begin{array}{c}\text { Tekanan } \\
(\mathrm{psia})\end{array}$ & $\begin{array}{c}\text { Solution } \\
\text { GOR } \\
(\mathrm{scf} / \mathrm{stb})\end{array}$ & $\begin{array}{c}\text { FVF Minyak } \\
(\mathrm{rb} / \mathrm{stb})\end{array}$ & $\begin{array}{c}\text { FVF Gas } \\
\text { (rb/scf) }\end{array}$ & $\begin{array}{c}\text { Viscositas } \\
\text { Minyak } \\
(\mathrm{cp})\end{array}$ & $\begin{array}{c}\text { Viscositas } \\
\text { Gas } \\
(\mathrm{cp})\end{array}$ \\
\hline 14.696 & 3.52215 & 1.13724 & 3.75354 & 0.993903 & 0.0148133 \\
\hline 213.716 & 30.2195 & 1.14985 & 55.2754 & 0.882591 & 0.0149504 \\
\hline 412.737 & 62.6723 & 1.16538 & 108.02 & 0.786554 & 0.0151592 \\
\hline 611.757 & 98.3997 & 1.18272 & 161.874 & 0.709722 & 0.0154176 \\
\hline 810.777 & 136.524 & 1.2015 & 216.688 & 0.647995 & 0.0157191 \\
\hline 1009.8 & 176.57 & 1.22151 & 272.278 & 0.597599 & 0.0160602 \\
\hline 1208.82 & 218.233 & 1.24262 & 328.43 & 0.555736 & 0.0164387 \\
\hline 1407.84 & 261.3 & 1.26474 & 384.9 & 0.520404 & 0.0168526 \\
\hline 1606.86 & 305.614 & 1.2878 & 441.43 & 0.490163 & 0.0173 \\
\hline 1805.88 & 351.051 & 1.31174 & 497.751 & 0.463961 & 0.0177787 \\
\hline 2004.9 & 397.512 & 1.33651 & 553.598 & 0.441014 & 0.0182861 \\
\hline 2203.92 & 444.917 & 1.36209 & 608.723 & 0.420731 & 0.0188198 \\
\hline 2402.94 & 493.198 & 1.38843 & 662.898 & 0.402655 & 0.0193768 \\
\hline
\end{tabular}




\begin{tabular}{|c|c|c|c|c|c|}
\hline 2601.96 & 542.297 & 1.41551 & 715.929 & 0.386429 & 0.0199542 \\
\hline 2800.98 & 592.164 & 1.44331 & 767.656 & 0.371771 & 0.0205491 \\
\hline 3000 & 642.756 & 1.47179 & 817.956 & 0.358452 & 0.0211588 \\
\hline 3200 & 694.289 & 1.46295926 & 866.975 & 0.346231 & 0.0217835 \\
\hline 3400 & 746.48 & 1.454181504 & 914.404 & 0.335023 & 0.0224179 \\
\hline 3600 & 799.301 & 1.445456415 & 960.212 & 0.324701 & 0.0230595 \\
\hline 3800 & 852.721 & 1.436783677 & 1004.39 & 0.315157 & 0.0237064 \\
\hline 4000 & 906.717 & 1.428162975 & 1046.96 & 0.306301 & 0.0243566 \\
\hline
\end{tabular}

Tabel 3 Permeabilitas relatif minyak dan air

\begin{tabular}{|c|c|c|}
\hline \multicolumn{3}{|c|}{ Tabel Permeabilitas Relatif (water-oil) } \\
\hline Sw & Krw & Krow \\
\hline 0.2 & 0 & 0.5 \\
\hline 0.234375 & 0.001563 & 0.439453 \\
\hline 0.26875 & 0.00625 & 0.382813 \\
\hline 0.303125 & 0.014063 & 0.330078 \\
\hline 0.3375 & 0.025 & 0.28125 \\
\hline 0.371875 & 0.039063 & 0.236328 \\
\hline 0.40625 & 0.05625 & 0.195313 \\
\hline 0.440625 & 0.076563 & 0.158203 \\
\hline 0.475 & 0.1 & 0.125 \\
\hline 0.509375 & 0.126562 & 0.095703 \\
\hline 0.54375 & 0.15625 & 0.070313 \\
\hline 0.578125 & 0.189062 & 0.048828 \\
\hline 0.6125 & 0.225 & 0.03125 \\
\hline 0.646875 & 0.264063 & 0.017578 \\
\hline 0.68125 & 0.30625 & 0.007813 \\
\hline 0.715625 & 0.351562 & 0.001953 \\
\hline 0.75 & 0.4 & 0 \\
\hline
\end{tabular}


Digunakan persamaan (Craft \& Hawkins, 1959) untuk menentukan harga Bo di atas tekanan gelembung sehingga model reservoir menjadi lebih representatif.

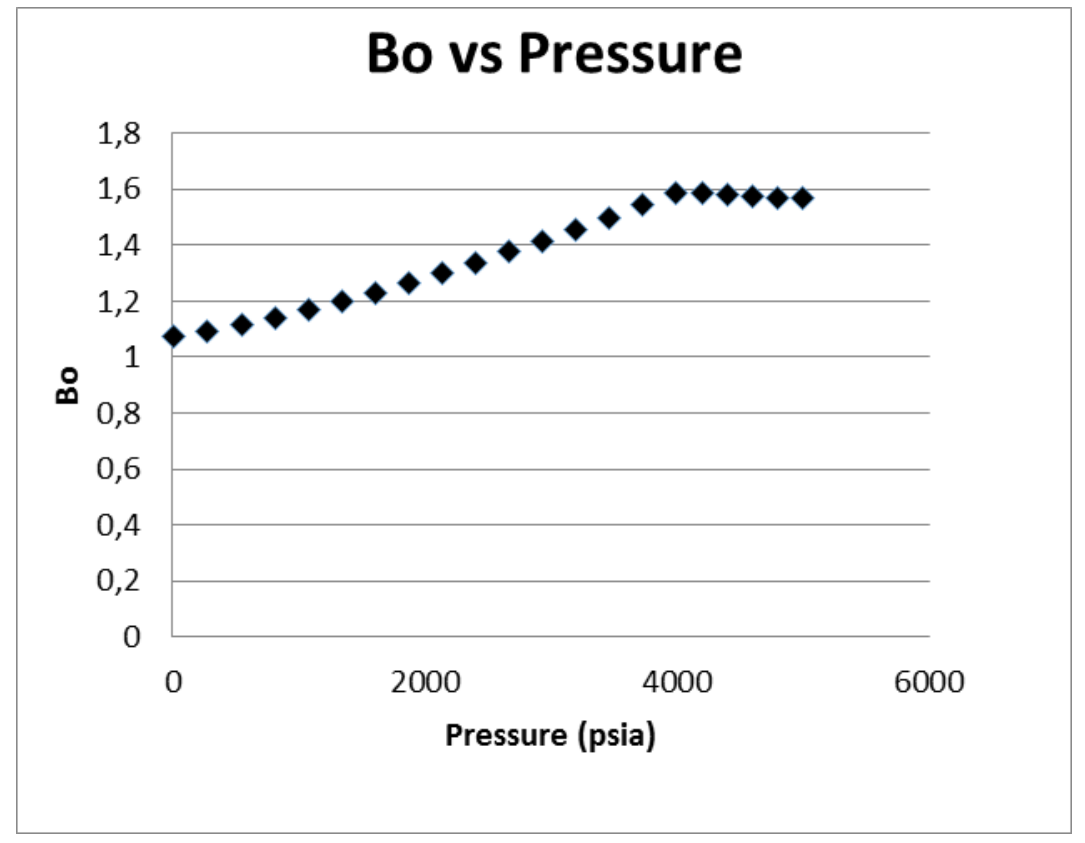

Gambar 2 Plot Bo terhadap tekanan setelah koreksi

Secara numerik, kompresibilitas minyak dapat dilihat dari data Bo sebagai berikut:

$$
c_{o}=-\frac{1}{B_{o_{n+\frac{1}{2}}}}\left(\frac{B_{o_{n+1}}-B_{o_{n}}}{p_{n+1}-p_{n}}\right)
$$

dan persamaan Bo di suatu tekanan

$$
B_{o_{n+1 / 2}}=\left(\frac{p_{n+1 / 2}-p_{n}}{p_{n+1}-p_{n}}\right)\left(B_{o_{n+1}}-B_{o_{n}}\right)+B_{o_{n}}
$$

Dengan menggabungkan persamaan (12) dan (13) maka diperoleh persamaan untuk menghitung harga Bo di atas tekanan gelembung sebagai berikut:

$$
B_{o_{n+1}}=B_{o_{n}}\left[\frac{c_{o}\left(\bar{p}-p_{n}\right)-c_{o} \Delta p+1}{c_{o}\left(\bar{p}-p_{n}\right)+1}\right]
$$

Setelah dilakukan koreksi perhitungan Bo dengan persamaan (14) maka grafik Bo di atas tekanan gelembung mengalami kenaikan seiring dengan berkurangnya tekanan (Gambar 2).

Waktu simulasi ditentukan berdasarkan persamaan (10) dengan mengambil asumsi awal batas reservoir atau jari-jari pengurasan, $\mathrm{r}_{\mathrm{e}}$, sebesar $1.5 \mathrm{kali}$ dari jari-jari model yang digunakan yaitu $15000 \mathrm{ft}$. Hal ini 
dilakukan untuk meningkatkan kepastian bahwa waktu yang diperoleh adalah waktu yang dibutuhkan transien tekanan untuk mencapai batas dari reservoir.

\section{STUDI KASUS}

Untuk mendapatkan analisa yang baik mengenai jari-jari pengurasan (drainage radius) atau batas reservoir dengan menggunakan kurva derivative, dilakukan pengaturan terhadap lamanya waktu penutupan sumur atau build-up time.

Pengaturan waktu yang digunakan menggunakan perbandingan waktu produksi dan waktu penutupan sumur. 3 model perbandingan yang digunakan yaitu 1:1, 1:2, dan 1:4. Model A merepresentasikan model perbandingan 1:1, model $\mathrm{B}$ untuk model perbandingan 1:2, dan model $\mathrm{C}$ digunakan untuk menyatakan model perbandingan 1:4. Selain itu, saat penutupan sumur, timestep yang digunakan juga dimodifikasi. 5 menit pertama penutupan sumur, timestep yang digunakan dalam skala waktu detik, 5 jam berikutnya dalam menit, 2 hari 18 jam berikutnya dalam jam, dan sisanya menggunakan skala hari.

Dari modifikasi timestep tersebut, akan diperoleh data tekanan yang diperoleh untuk pengujian sumur dan penentuan karakteristik reservoir, yaitu permeabilitas dan jari-jari pengurasan dengan menggunakan software Saphire menjadi lebih akurat.

Hasil yang diperoleh untuk model A menunjukkan hasil permeabilitas yang berbeda dengan nilai permeabilitas yang digunakan pada software CMG. Bentuk kurva log-log plot tekanan, derivative dan waktu dapat dilihat pada gambar 3.

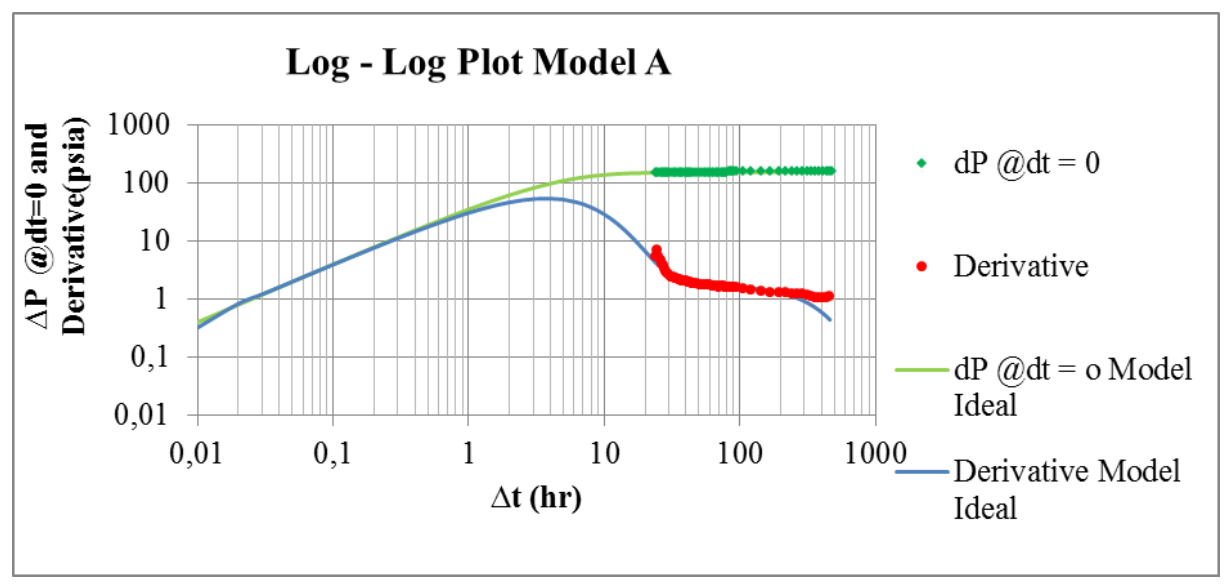

Gambar 3 Kurva Log-log Plot Model A

Dari hasil interpretasi dengan menggunakan software Saphire, bentuk kurva log-log plot yang diperoleh berbeda dengan bentuk model ideal yang tersedia pada software Saphire. Model ideal yang mendekati adalah model constant wellbore storage, jenis sumur vertical well, model reservoir yaitu homogeneus reservoir, dan boundary reservoir berupa circle. Dari hasil matching dapat dilihat nilai permeabilitas dan batas reservoir untuk model A.

Analisa kemudian dilanjutkan untuk reservoir dengan waktu penutupan sumur yang lebih lama yaitu B. Dari hasil interpretasi, bentuk kurva derivative sedikit berbeda dengan bentuk kurva derivative model A. Pada kurva derivative untuk model A, bentuk akhir kurva masih menunjukkan kecenderungan 
gradien 0. Berbeda dengan model B, bentuk akhir kurva derivative lebih jatuh, seperti yang ditunjukkan gambar 4. Nilai permeabilitas yang diperoleh juga lebih besar dari permeabilitas model A. Sedangkan untuk batas reservoir, $\mathrm{r}_{\mathrm{e}}$, menunjukkan range nilai yang lebih besar.

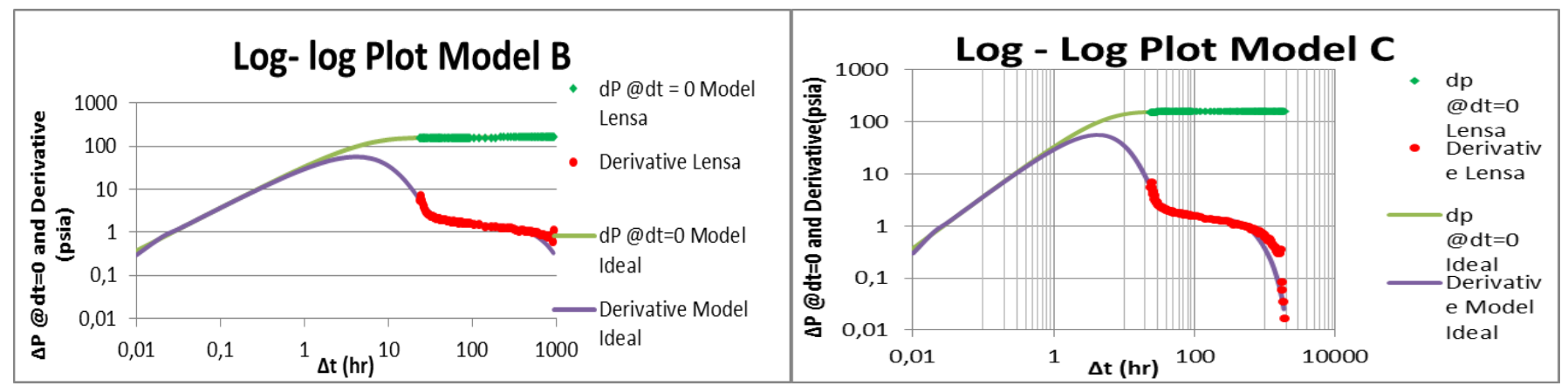

Gambar 4 Kurva Log-log Plot Model B

Gambar 5 Kurva Log-log Plot Model C

Model perbandingan terakhir yaitu model $\mathrm{C}$ lebih menunjukkan perbedaan dibandingkan dengan model-model sebelumnya. Bentuk kurva derivative yang dihasilkan oleh model ini menunjukkan adanya closed system dan sealing di batas reservoir. Hal ini semakin memastikan kecocokan dengan model yang telah dibuat dengan menggunakan software CMG sebelumnya. Gambar 5 menunjukkan bentuk kurva derivative dari model ini.

Hasil-hasil interpretasi nilai permeabiltas dan jari-jari pengurasan dari ketiga model ini ditunjukkan pada gambar 6 dan 7.

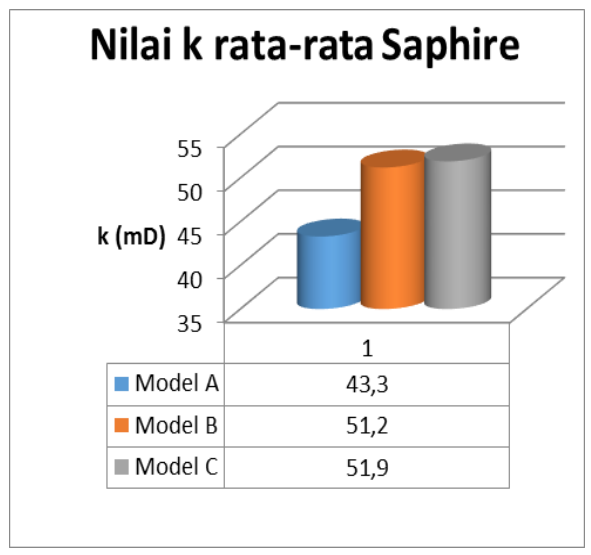

Gambar 6 Hasil Interpretasi Permeabilitas

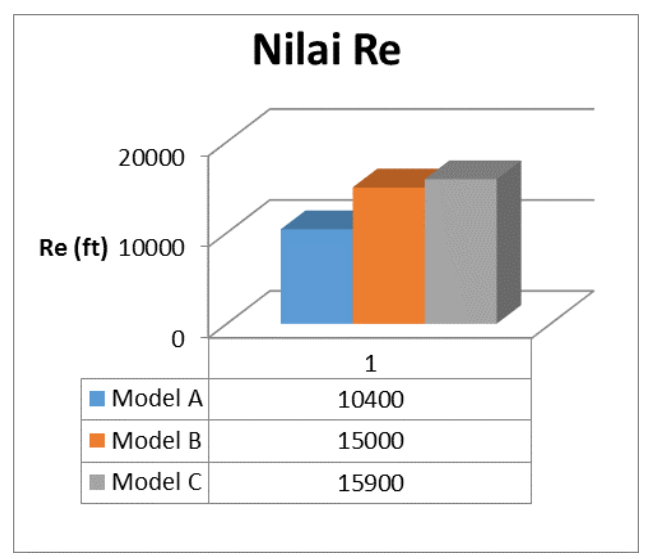

Gambar 7 Hasil Interpretasi $r_{e}$

Dari ketiga model ini, dapat dilihat kesamaan mengenai bentuk kurva derivative dari model reservoir lensa ini tidak mengikuti bentuk ideal yang digunakan pada software Saphire. Sehingga untuk itu, harus dapat dianalisa kembali nilai permeabilitas dan jari-jari pengurasan atau batas reservoir yang diperoleh. Kita dapat menggunakan sensitivitas nilai permeabilitas dan batas reservoir untuk memastikan rentang nilai properti reservoir. Hasil sensitivitas tersebut ditunjukkan pada gambar 8, 9,10,11,12 dan 13 untuk masing-masing model perbandingan. 
Rentang nilai yang diperoleh menunjukkan kecenderungan tertentu terutama untuk nilai data permeabilitas. Sedangkan untuk batas reservoir, didapat kecenderungan semakin lama waktu penutupan sumur, semakin besar nilai batas reservoir yang ditunjukkan dari hasil interpretasi software.

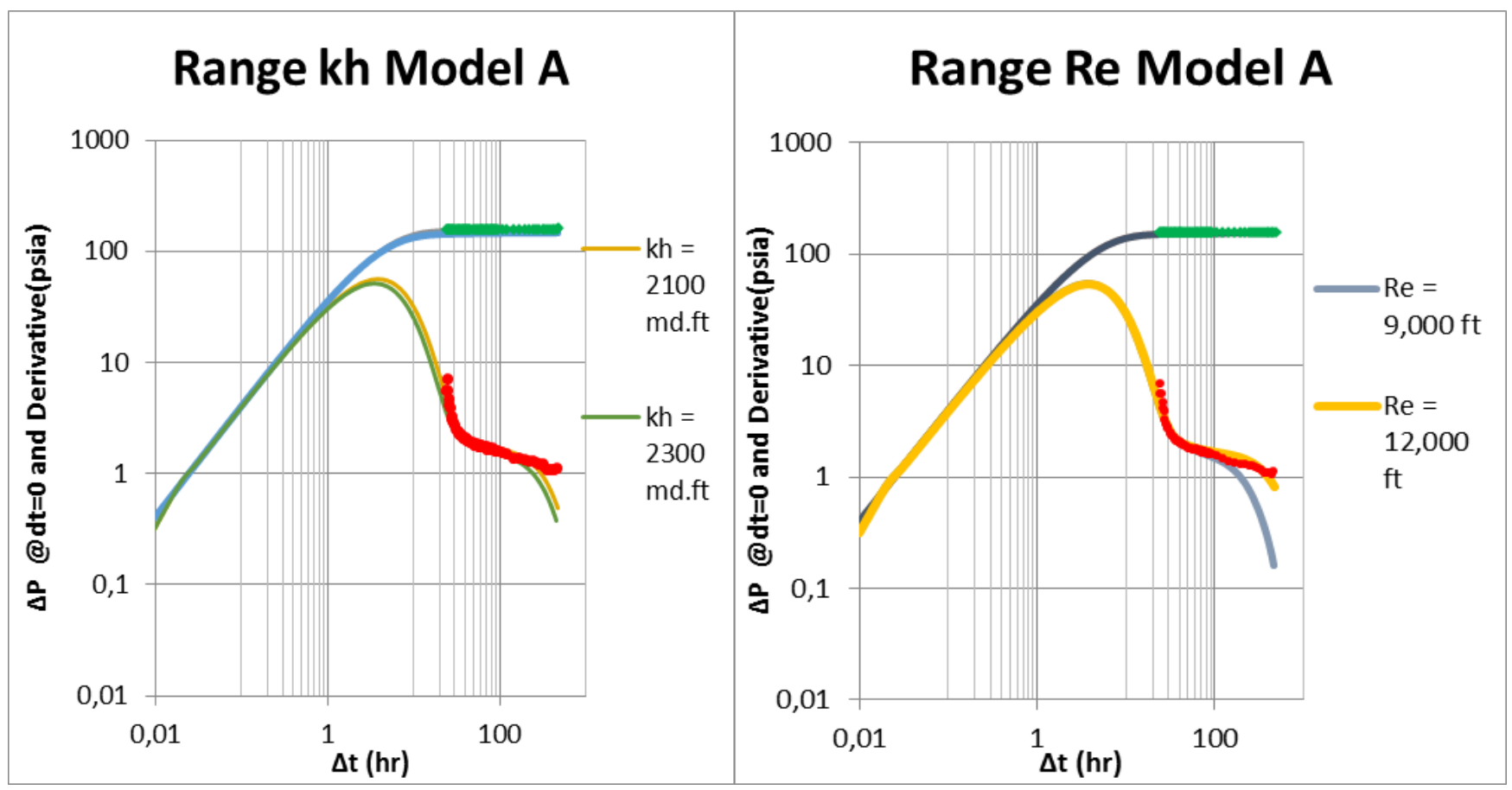

Gambar 8 Hasil sensitivitas kh model A

Gambar 9 Hasil sensitivitas batas reservoir model A

Permeabilitas rata-rata yang diperoleh berdasarkan hasil matching dengan menggunakan software Saphire memiliki nilai yang jauh lebih kecil jika dibandingkan dengan nilai permeabilitas yang digunakan pada model reservoir lensa software CMG. Perbedaan permeabilitas ini cukup signifikan mengingat nilai permeabilitas pada software CMG sebesar $100 \mathrm{mD}$ sedangkan hasil yang ditunjukkan oleh software Saphire berkisar antara 40-52 mD. Perbedaan permeabilitas ini dapat disebabkan beberapa hal. Pertama adalah model yang dimiliki bukan merupakan satu fasa minyak. Adanya sejumlah air yang memberikan nilai saturasi sehingga mempengaruhi permeabilitas relatif. Dari model diperlihatkan saturasi air mula-mula sebesar 0.2 dan saturasi air pada waktu penutupan mengalami sedikit perubahan menjadi 0.200003. Gambar 13 memperlihatkan sedikit perubahan saturasi dari awal hingga akhir pengujian. Dari Tabel 3 menunjukkan pada saturasi air 0.2 , permeabilitas relatif minyak sebesar 0.5. Hal ini menyebabkan permeabilitas efektif yang dimiliki oleh minyak tidak mengikuti permeabilitas absolut yang diinput sehingga hasil yang ditunjukkan Saphire memberikan perbedaan. Seperti yang diketahui bahwa permeabilitas efektif minyak merupakan permeabilitas relatif dikali dengan permeabilitas absolut. Dengan nilai permeabilitas absolut sebesar $100 \mathrm{mD}$ dan permeabilitas relatifnya adalah 0.5 , maka hasil yang ditunjukkan oleh Saphire adalah cocok. Tabel 4 menunjukkan besaran error dari permeabilitas. Kedua adalah adanya pengaruh bentuk reservoir lensa. Pada input awal software Saphire, ditentukan ketebalan reservoir. Untuk reservoir lensa, sulit untuk menentukan berapa ketebalan reservoir rata-rata, sehingga dapat memberikan perbedaan nilai permeabilitas. Rentang nilai permeabilitas untuk ketiga model dapat dilihat pada tabel 5. 
Tabel 4 Hasil Matching k dan $r_{e}$ pada Saphire

\begin{tabular}{|c|c|c|c|}
\hline Model & $\mathrm{k}$ avg $(\mathrm{mD})$ & Error k $(\%)$ & $\mathrm{r}_{\mathrm{e}}(\mathrm{ft})$ \\
\hline A & 43.3 & 13.4 & 10400 \\
\hline B & 51.2 & 2.4 & 15000 \\
\hline C & 51.9 & 3.8 & 15900 \\
\hline
\end{tabular}

Tabel 5 Hasil Interpretasi - Uji sensitivitas kh

\begin{tabular}{|c|c|c|}
\hline \multirow{2}{*}{ Model } & \multicolumn{2}{|c|}{ kh (mD.ft) } \\
\cline { 2 - 3 } & minimum & maksimum \\
\hline \hline A & 2100 & 2300 \\
\hline B & 2450 & 2650 \\
\hline C & 2500 & 2700 \\
\hline
\end{tabular}

Batas reservoir yang diperoleh dari software Saphire ini sangat berguna untuk pengembangan reservoir lensa terutama penentukan lokasi sumur baru baik berupa sumur produksi maupun sumur injeksi untuk pressure maintanance. Namun kecenderungan semakin besarnya batas reservoir mengikuti lamanya penutupan sumur memberikan pengetahuan bahwa lamanya penutupan sumur tidak selamanya memberikan data-data yang sangat akurat. Terlepas dari model $\mathrm{C}$ menunjukkan bentuk kurva derivative yang lebih baik, tetapi nilai batas reservoir yang diberikan juga tidak terlalu akurat jika dilihat berdasarkan bentuk model yang digunakan pada software CMG.

Namun rentang batas reservoir yang diperoleh masih dapat diterima, berkisar diantara jari-jari pengurasan berdasarkan model reservoir dari software CMG. Nilai rentang batas reservoir hasil interpretasi software Saphire untuk ketiga model yang digunakan dapat dilihat pada tabel 6.

Tabel 6 Hasil Interpretasi - Uji Sensitivitas drainage radius $\left(\mathrm{r}_{\mathrm{e}}\right)$

\begin{tabular}{|c|c|c|}
\hline \multirow{2}{*}{ Model } & \multicolumn{2}{|c|}{$\mathrm{r}_{\mathrm{e}}(\mathrm{ft})$} \\
\cline { 2 - 3 } & minimum & Maksimum \\
\hline \hline A & 9000 & 12000 \\
\hline B & 13000 & 17000 \\
\hline C & 13000 & 18000 \\
\hline
\end{tabular}




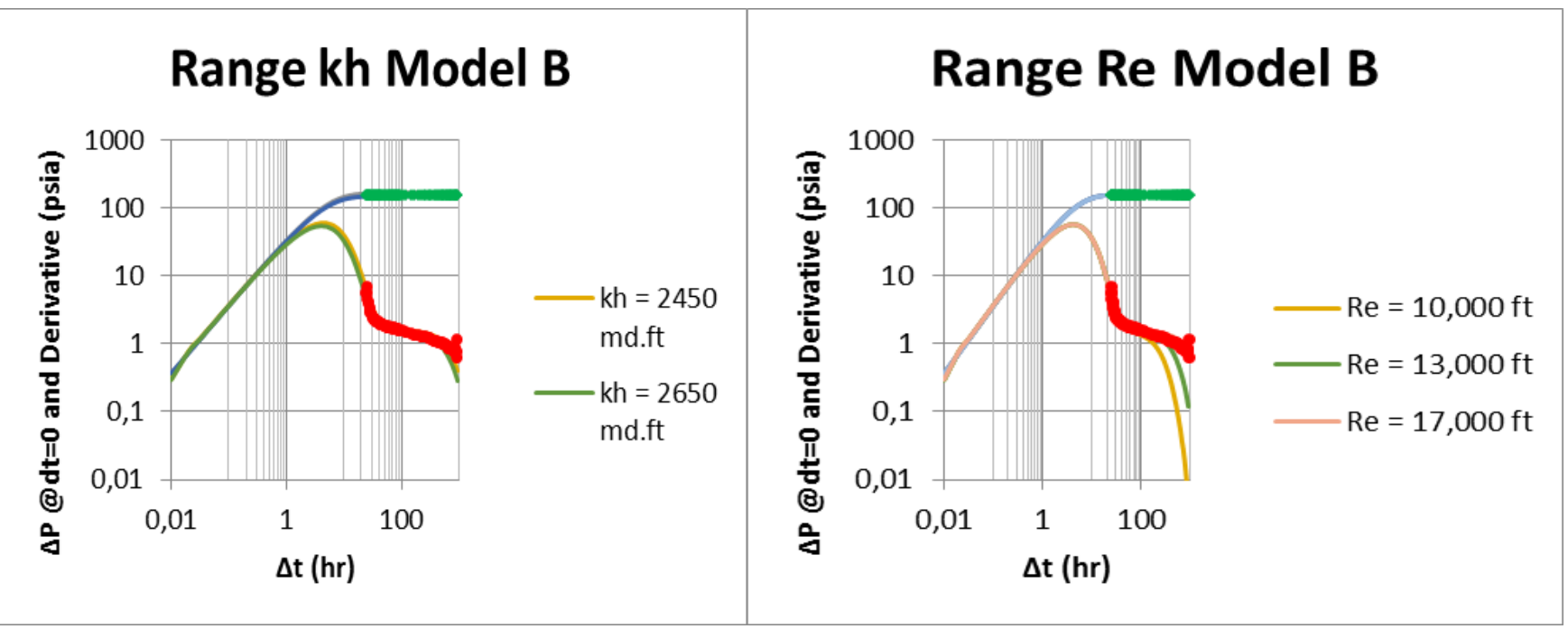

Gambar 10 Hasil sensitivitas kh model B Gambar 11 Hasil sensitivitas batas reservoir model B

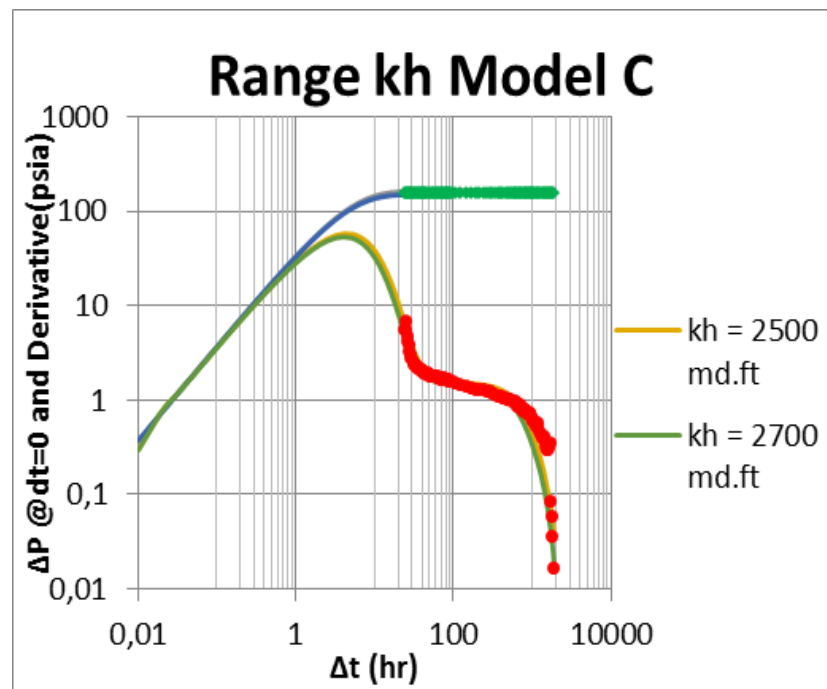

Gambar 12 Hasil sensitivitas kh model C

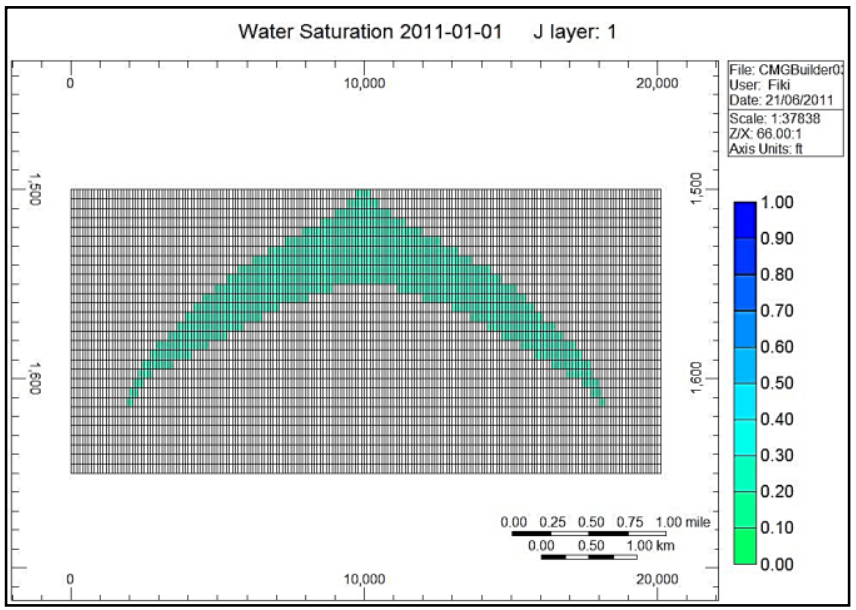

Gambar 14 Saturasi air mula-mula

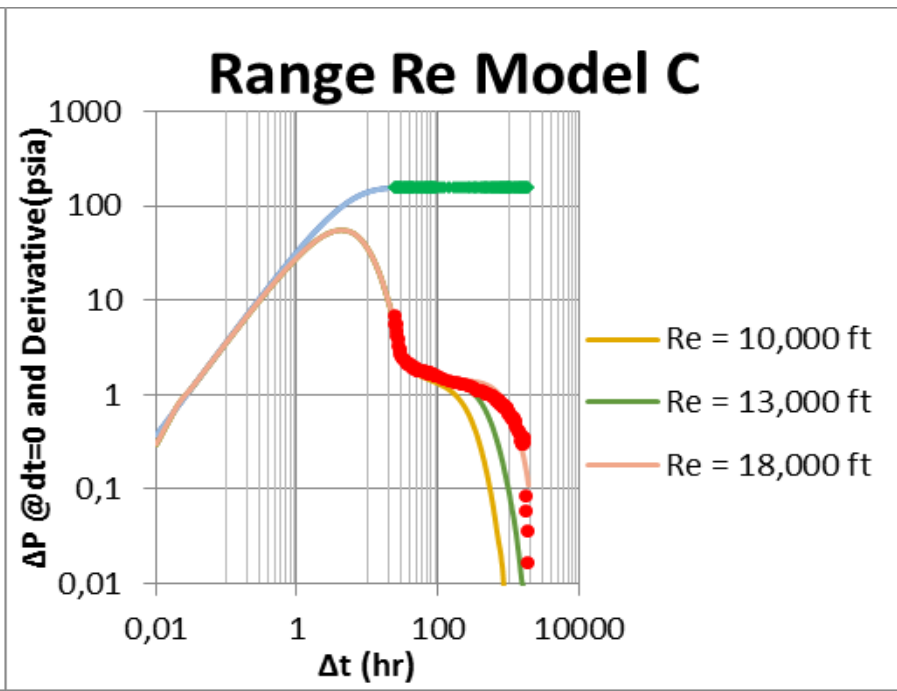

Gambar 13 Hasil Sensitivitas Re model C

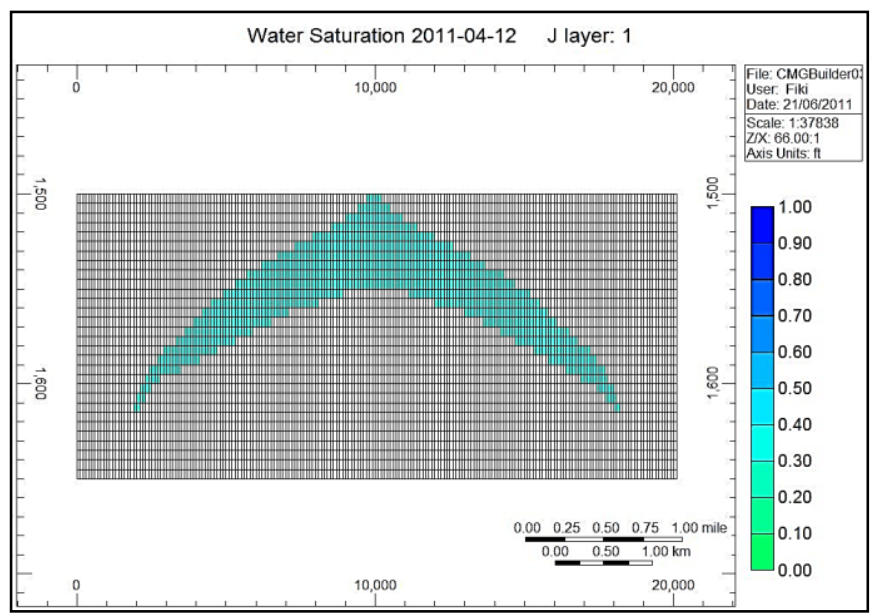

Gambar 15 Saturasi akhir pengujian 


\section{KESIMPULAN}

1. Pengaturan timestep pada penutupan sumur dimulai dari detik,menit,jam dan hari sangat diperlukan untuk memperoleh data tekanan transien yang lebih baik.

2. Pengaturan waktu penutupan diperlukan untuk menentukan lamanya waktu yang efektif untuk pengujian sumur jika dilakukan build-up.

3. Bentuk kurva derivative reservoir lensa tidak mengikuti bentuk ideal dari model reservoir homogeneus dengan boundary circle.

4. Analisa reservoir lensa dengan model reservoir horizontal yang tertutup dapat dilakukan dengan hasil batas reservoir dan nilai permeabilitas yang cukup baik.

5. Nilai permeabilitas yang ditunjukkan oleh Saphire berbeda akibat model memiliki 2 fasa, yaitu minyak dan air, sehingga permeabilitas efektif minyak berbeda dengan permeabilitas absolut.

\section{DAFTAR SIMBOL}

$\Phi \quad=$ porositas, fraksi

$k \quad=$ permeabilitas, $\mathrm{mD}$

$\mu \quad=$ viskositas, $\mathrm{cp}$

$t_{s} \quad=$ Stabilized time, $\mathrm{hr}$

$r_{i} \quad=$ jari-jari pengamatan, $\mathrm{ft}$

$r_{e} \quad=$ jari-jari pengurasan atau batas reservoir, $\mathrm{ft}$

$P_{i} \quad=$ tekanan awal, psia

$B_{o i} \quad=$ faktor volume formasi minyak awal, $\mathrm{bbl} / \mathrm{STB}$

$B_{o} \quad=$ faktor volume formasi minyak, bbl/STB

$C_{o} \quad=$ kompresibilitas minyak, $\mathrm{psi}^{-1}$

$C_{t} \quad=$ kompresibilitas formasi batuan, $\mathrm{psi}^{-1}$

\section{DAFTAR PUSTAKA}

Boardman, C. R., \& Knutson, C. F. (1981). UINTA Basin Lenticular Sandstone Reservoir Characteristics. The SPE/DOE Low Permeability Symposium. Denver: SPE.

Craft, B. C., \& Hawkins, M. F. (1959). Applied Petroleum Reservoir Engineering. New Jersey: Prentice-Hall.

Craig, D. P., \& Brown, T. D. (1999). Estimating Pore Pressure and Permeability in Massively Stacked Lenticular Reservoirs Using Diagnostic Fracture-Injection Tests. the 1999 SPE Annual Technical Conference and Exhibition. Houston: SPE.

Earlougher Jr, R. C. (1977). Advances in Well Test Analysis. Dallas: Society of Petroleum Engineers of AIME.

Evans, R. D., \& Carroll, H. B. (1981). Stochastic Modeling of Fractured Gas Wells Completed in Low Permeability Noncontinuous Lenticular Reservoirs. The 1981 SPE/DOE Low Permeability Symposium. Denver: SPE.

Horner, D. R. (1951). Pressure Build-Up in Wells. Third World Pet. Cong (pp. 503-523). The Hague: Society of Petroleum Engineers of AIME.

Hubbert, M. K. (1940). The Theory of Ground-Water Motion. J. of Geol, 785-944.

Lee, J. (1982). Well Testing. New York: Society of Petroleum Engineers of AIME. 
Lorenz, J. C. (1985). Predictions of Size and Orientations of Lenticular Reservoirs in the Mesaverde Group, Northwestern Colorado. The SPE/DOE 1985 Low Permeability Gas Reservoirs. Denver: SPE.

Matthews, C. S., \& Russell, D. G. (1967). Pressure Buildup and Flow Tests in Wells. Dallas: Society of Petroleum Engineers of AIME.

van Everdingen, A. F., \& Hurst, W. (1949). The Application of the Laplace Transformation to Flow Problems in Reservoirs. Trans AIME, 305-324.

Warpinski, N. R., Branagan, P., Sattler, A. R., Lorenz, J. C., Worthrop, D. A., Mann, R. L., \& Frohne, K. H. (1985). Fracturing and Testing Case Study of Paludal, Tight, Lenticular Gas Sands. The 1985 SPE/DOE Symposium on Low Permeability Reservoirs. Denver: SPE.

Zubari, H. K., \& Abdulwahab, A. E. (1999). The Role of Sequential Welltesting in Improving Oil Recovery from a Closed Sand Lens. the 1999 SPE Middle East Oil Show. Bahrain: SPE. 